\title{
The Implementation of Doelmatigheid Principle in the Procurement of Government's Goods and Services to Prevent the Criminal Act of Corruption
}

\author{
Laurencia Wibisono and Farra Indhira Kirana \\ Master of Notary, Faculty of Law Airlangga University \\ Surabaya, Jawa Timur \\ Indonesia
}

\begin{abstract}
The criminal act of corruption in the procurement of government's goods and services becomes the second biggest case of corruption after bribery. This case happens because there is no proper and immediate prevention for the corruption. Actually, the criminal act of corruption in the procurement of government's goods and services can be prevented by the principle of doelmatigheid, so that the procurement of goods and services do not only focus on the formal procedure (rechtmatigheid), but it must also give the benefits to the people in order to improve the public services for our social welfare.
\end{abstract}

Key Words: Doelmatigheid Principle, Procurement of Goods and Services, Anti-Corruption.

\section{INTRODUCTION}

The criminal act of corruption in the procurement of government's goods and services in Indonesia is not a new issue. Even, it has been a very fertile land for the corruptors involving officials in executive and legislative. It can be proven from 148 cases of the criminal act corruption which have been handled by Corruption Eradication Commission (KPK) from 2004 to 2016 and this case is the second highest corruption case after bribery [1].

This corruption case has been a big concern because it does not only cause the financial loss for our country, but it also causes a crucial loss for our community because the quality of some public facilities will decline, which can cause damages that can harm our people. Therefore, the criminal act of corruption in the procurement of goods and services has more massive impacts than the criminal act of corruption in other cases.

Related to that case, Indonesia Procurement Watch (IPW) has identified some factors causing the criminal act of corruption in the procurement of government's goods and services as the followings: (1) weak condition of legal and institutional framework; (2) weak capacity of the manager in the procurement of government's goods and services; (3) weak obedience to the rules, their supervision and their enforcement. Furthermore, Emil Salim as quoted by Amiruddin strictly confirmed that, "There are about five vulnerable points of corruption in the procurement of government's goods and services in Indonesia as the followings, (i) in the planning process starting from identifying the project and the feasibility study; (ii) in the system being used; (iii) in the process to get the deal of business contracts or business projects; (iv) in the use of official's authority; and (v) in the completion of the list of project contents (DIP) and the payment of DIP which can be the target of corruption." [2].

In general, the corruption can be formulated by a simple equation by Robert Klitgaard, et.al., which stated that the corruption originally comes from the existence of monopoly power supported by the authority of discretion by officials, but without accountability. Therefore, he formulated the corruption simply with the equation: $\mathrm{C}$ (corruption) $=\mathrm{M}$ (monopoly power) $+\mathrm{D}$ (discretion by officials) - A (accountability) [3]. When we consider that corruption formula, it is not enough to have only the authority (bevoegdheid) which comes from the legislation (rechmatigheid). The reason for that statement is that even though we execute the authority very obediently (bevoegdheid) according to the legislation (rechtmatigheid), there is no guarantee to eliminate any opportunities of corruption.

The comprehensive and strict rules will not guarantee that the criminal act of corruption in the procurement of government's goods and services disappears. To prove that statement, many policies have been issued to prevent misapplication in the 
procurement of government's goods and services starting from Presidential Decree (Keppres) Number 18 in the year of 2000 about The Procurement of Goods or Services until Presidential Regulation (Perpres) Number 54 in the year of 2010 about The Procurement of Government's Goods and Services, including its amendments. All those regulations and policies cannot prevent the criminal act of corruption in the procurement of government's goods and services. Hence, it is obvious that strict legislations (laws and regulations) cannot stop the damaging impacts of corruption. Therefore, we can conclude that the implementation of the principle "the execution of government according to the law" or it is usually known as the principle of rechtmatigheid which becomes a fundamental principle in the law-based country, which has not been effective to prevent the criminal act of corruption in the procurement of government's goods and services.

Based on that statement, we need a new paradigm in the procurement of government's goods and services to prevent and eliminate any corruptions causing massive losses by implementing the principle of doelmatigheid in addition to the principle of rechtmetigheid. In the perspective of administration law, we frequently see the term doelmatigheid in the construction of public policy and in the activities of state officials. Literally, doelmatigheid has the meaning of "usefulness, benefit, usability, benefits and goals" [4].

Related to that statement, Sudikno Mertokusumo stated that, "in the law of administration, discretionary power must have doelmatigheid or goals according to bevoegdheid" [5]. Therefore, it is very important that the authority of the officials in implementing the procurement of government's goods and services does not only focus on their obedience to the rules (rechtmatigheid), but it must also pay attention to the usefulness or benefit (doelmatigheid), so that the officials will not misuse the authority which can cause the corruptions. Therefore, it is required to have a change in the mindset from thinking legally to thinking usefully, so that the procurement of government's goods and services does not only focus on the principle of rechtmatigheid, but it must also pay attention to the principle of doelmatigheid.

Based on the explanation mentioned above, there is a fundamental question that says, "Can the principle of doelmatigheid prevent the act of corruption in the procurement of government's goods and services?".

\section{METHOD AND MATERIALS}

This study is a law research, which is a process to find the rules of law, the law principles, or the law doctrines in order to answer to the law issues [6]. For answering the law issues stated in the study, we use two approaches, which are statute approach and conceptual approach.

The statute approach is to apply the rules of statute which are related to the procurement of government's goods and services and the eradication of the act of corruption, including the Constitution Number 31 in the year of 1999 about The Eradication of the Act of Corruption and Presidential Regulation (Perpres) Number 54 in the year of 2010 about The Procurement of Government's Goods and Services. Other than that, this study also applies the conceptual approach which is to elaborate the law concepts, which are related to the application of doelmatigheid principle in the procurement of government's goods and services in order to prevent the act of corruption for solving or answering the law issues or problems [7].

\section{RESULT AND DISCUSSIONS}

The word "corruption" comes from Latin which means "corruptio" or "corruptus", that was stated by Poerwadarminta as quoted by Andi Hamzah, defined as a bad deed like money laundering, bribery, and other typical activities [8]. Contrasting to that statement, Benveniste as quoted by Suyatno, defined the corruption in a broader way classified into 4 criteria as the followings:

1) Discretionary corruption, which is a corruption that is executed because of a freedom in determining the policy though it seems legal;

2) Illegal corruption, which is a corruption that has a purpose to destruct the terms or goals of laws, rules and certain regulations;

3) Mercenary corruption, which is a corruption that has a purpose to gain a personal profit through the authority manipulation;

4) Ideological corruption, which is an illegal corruption or discretionary that has a purpose to achieve the team's goal. [9]

Based on the statements mentioned above, the seventh paragraph of the preamble of United Nation Convention Against Corruption (UNCAC) as ratified through the Constitution Number 7 in the year of 2006 about the ratification of United Nation Convention Against Corruption emphasizes the serious impact of four categories of corruptions as the followings destroying the construction of democracy in a country, causing the financial loss and ruining the foundation of the law-based country. It means that a democracy institution, national economic power, and the law-based country's principle become the target of damaging act 
of corruption. Therefore, if those three important pillars collapse, the life existence of prosperous country and the people will be extinct. It has been noted in the fact of history that big group of market in the era of Dutch colonialism, called VOC, was vanished because of the act of corruption.

From observing that impact, it will be more fatal if it takes place in the procurement of government's goods and services because philosophically the procurement of government's goods and services is executed to improve the public service to serve the public needs for creating the social welfare. As confirmed and considered in the letter a of Presidential Regulation (Perpres) Number 54 in the year of 2010 about The Procurement of Government's Goods and Services which says that, "The efficient, open and competitive procurement of government's goods and services is very necessary for the supply of affordable and quality goods or services, so that it will have a good impact for improving the public service".

As discussed in the previous statements, the act of corruption in the procurement of government's goods and services can cause not only in the country's financial loss, but it can also cause a defect of the user of the public service or facility that is engaged through the procurement of goods and services. If observed carefully, the act of corruption in the procurement of government's goods and services is likely related to the good behaviour of the officer in engaging the procurement of goods and services that can contribute positively to the public's benefit because until now the officer has only been considering to save himself or herself from the trap of the law. It means that the procurement officials most likely focus more on the legal procedure in the rules of statute to avoid any lawsuits in the future.

The behaviour of the procurement official using the law instrument in the procurement of government's goods and services as a protection from the lawsuit is very common in the law-based countries. The purpose is to enforce the law itself as the highest authority in the law-based country. It means that no official or no citizen has a higher position than the law itself. According to the previous statement, Wade stated that everything must be done according to law in the country. Law-based country determines that the government only obeys to the law, and it is not for the law to obey the government [10]. According to the previous statement, Algra and Jansen stated that the law-based countries enact the law to be the rule of game in organizing the state administration, government and society, while the goal of the law itself is "...opgelegd om de samenleving vreedzaam, rechtvaardig, en doelmatig to ordenen" [11].

Meanwhile, the law-based country according to Bothling is "de staat, waarin de wilvriheid van gezagsdragers is beperket door grenxen van recht" [12]. Furthermore, he said that realizing the limitation of the authority holder can be executed by "Enerzids in een binding van rechter en administratie aan de wet, anderjizds in een begrenzing van de bevoegdheden van wetgever" [13]. Referring to those arguments, it is clear that in the law-based country every activity of the state officials and the citizens must follow and obey to the law. It means that every execution of living in the nation and the state must have the law foundation as a legal measurement of organizing the nation. This concept should be embedded in the procurement process of government's goods and services, which is that every procurement of government's goods and services must obey to the determined rule of law as a primary reference in engaging the procurement of government's goods and services.

The basic obedience and submission to the law in the procurement of government's goods and services are implicitly stated in the Article 1 item 1 of Presidential Regulation (Perpres) Number 54 in the year of 2010 about The Procurement of Government's Goods and Services which states that "The Procurement of Government's Goods and Services which will be called The Procurement of Goods and Services is the activities to have goods and services by the Ministry or Institution or the Operational Unit of Regional Division or other Institutions. These activities are started from the planning of needs up to the completion of all activities to get the goods and services." This rule means that every procurement of government's goods and services must be preplanned well at first and then must be executed based on the plan. Therefore, if there is no plan, there won't be any execution or every procurement official cannot execute the procurement process unless it is planned well before. Therefore, this planning has a very important position because it becomes a reference in the procurement of government's goods and services.

Nevertheless, there will be a fundamental problem if we have some unplanned needs because those needs appear after the legal officials determine the plan. Therefore, those needs are not included in the state or regional budget or there are well-planned needs which are already executed independently by the people using their own fund. If we notice to the legal aspects, our government must determine the budget of modification, but its procedure and mechanism will take a long time although the procurement needs are so urgent. This problem will interfere the effectiveness of public service and it does not reflect to the principle of effectiveness as ruled in the Article 5 letter b of Presidential Regulation (Perpres) Number 54 in the year of 2010 about The Procurement of Government's Goods and Services.

Based on the previous statement, it is necessary to have a combination of legality and utility. It means that we do not only apply the principle of rechtmatigheid, but we must also apply the principle of doelmatigheid, so that the procurement of government's goods and services can be executed well in order to improve the public services and it can also serve the public needs. 
Related to that point, E. Utrecht as quoted by Prajudi Atmosudirdjo stated that, "A government's action in organizing the nation is the utilization or usefulness (doelmatigheid) is more important than its appropriateness related to the positive law (rechtmatigheid)" [14]. And then, in the relationship between the principle of rechtmatigheid and the principle of doelmatigheid, Sudikno Mertokusumo confirmed that, "The principle of rechtmatigheid is a principle that was born from a law-based country whose function is to create the law certainty in a country. And then, the principle of rechtmatigheid has an abstract characteristic and it can be perceived clearly when implemented in the community. Whereas the principle of doelmatigheid is a principle that had been born before the principle of rechtmatigheid was born. The substance of this doelmatigheid principle is utilization (usefulness), in which the utilization is a foundation in the law formation." [15]. Referring to that argument, the principle of doelmatigheid has a higher priority than the principle of rechtmatigheid. Therefore, if there is a conflict between the two principles, the principle of doelmatigheid will be more prioritized than the principle of rechtmatigheid.

Furthermore, to strengthen that argument, it is necessary that we state the theory of law relevant to this discussion, which is the theory of law's purpose stated by Gustav Radbruch. The principle of doelmatigheid is actually in accordance to the purpose stated by Gustav Radbruch as cited by Ahmad Ali saying that "The law must contain three identity values which are, (1) the principle of justice (gerectigheid) which is viewed philosophically; (2) the principle of utilization (zwechmatigheid/doelmatigheid/utility), which is viewed sociologically; and (3) the principle of legal certainty (rechtssicherheid/rechtmatigheid), which is viewed juridically" [16].

Those Gustav Radbruch's arguments can be divided gradually into their priority levels, which are justice (gerectigheid), utilization (zwechmatigheid/doelmatigheid), and legal certainty (rechtssicherheid/rechtmatigheid). Therefore, if there is a conflict between those three basic values (grundwerten), the higher priority principle will set aside the lower priority principle, for example if there is a conflict between the principle of utilization and the principle of legal certainty, so the principle of utilization will set aside the principle of legal certainty. Nevertheless, it is better if we can harmonize those three basic values like triangular concept from Werner Menski, saying that "justice, utilization, and legal certainty can proceed harmoniously because in every justice we must have a benefit (utility) and every justice and utilization have been embodied into the rules of statute which becomes a specific characteristic of legal certainty" [17].

Based on those statements, the procurement of government's goods and services is based on the principle of rechtmatigheid which prioritizes legal certainty more than other law's purposes. It is very common because Indonesia as a law-based country as stated in the Article 1 chapter (3) The Constitution of the State of the Republic of Indonesia in 1945 saying that, "Indonesia is a law-based country." Therefore, every execution of the country's policy must be based on the law either in written ways or in verbal ways. Nevertheless, we need a harmony between the legal certainty as a basic element of the law-based country and the utilization that becomes a sociological need. Therefore, it is also important to notice the principle of doelmatigheid beside the principle of rechtmatigheid in the procurement of government's goods and services because the corruption in the procurement process cannot be prevented continuously without the application of the principle of doelmatigheid. That statement has been proven in the history of organizing the procurement of government's goods and services which has changed a lot since we used the Presidential Decree until we used Presidential Regulation (Perpres) Number 54 in the year of 2010 about The Procurement of Government's Goods and Services, including its amendments.

Based on that statement, the prevention of the act of corruption in the procurement of government's goods and services should not be only conducted based on the principle of rechtmatigheid, but it should be also conducted based on the principle of doelmatigheid because improving the public services through the procurement of government's goods and services prioritizes mainly on the utilization (benefits) for the people. It means that although the procurement process has been executed obediently to the law (rechtmatigheid), we cannot confirm that the result of the procurement has a good quality like the public expectation. Even, in the procurement of the construction service like developing the transportation roads, the corruption often occurs. It can happen not because of having the wrong procedure as stated in the rule of law, but it happens because of the declining quality, so that the roads are vulnerable to damage before the trial period ends, which causes many losses for the people. This problem is one of the empirical facts that following the procedure does not mean that we are free from the corruptions. Therefore, it is very important to notice the principle of doelmatigheid beside the principle of rechtmatigheid in order to realize the improvement of public services through the procurement of government's goods and services, which gives direct benefits to the people as the fundamental purpose of the procurement process.

If necessary, as long as the procurement of government's goods and services gives benefits for the people and it does not cause the national or regional financial loss, so that the procurement officials must have a law protection even though it is not in accordance to the procedure ruled in the rule of law. This thing happens because the principle of doelmatigheid has a higher priority than the principle of rechtmatigheid. 
Furthermore, in the perspective of the law of administration, the term is known as discretionary power which means that the official can give discretion to overcome the government's stagnation. Therefore, discretionary power becomes a foundation to take important steps in the procurement of government's goods and services that gives benefits for the people.

\section{CONCLUSIONS}

Considering and observing the discussion above, we can conclude that principle of doelmatigheid in the theory of law's purposes has a higher position than the principle of rechtmatigheid. Therefore, if there is a conflict between the two principles, the principle of doelmatigheid must be prioritized, so that the principle of rechtmatigheid should be set aside. Nevertheless, those two principles should strengthen each other as discussed in the triangular concept. In the procurement process, we often see that the procurement of government's goods and services which is conducted on procedure determined by the rule of law (rechtmatigheid) has a chance to have an indication of corruption because of declining quality of goods and services that cannot be used before the trial period ends.

Observing the previous statements, it is necessary to have a new paradigm in the procurement of government's goods and services, in which we do not only perceive the legal aspect, but we must also see the utility aspect. Therefore, it is important to combine the principle of rechtmatigheid with the principle of doelmatigheid because we cannot solve the problems of corruptions in the procurement process only by being obedient to the rule of law, but we can observe unachieved benefits for the people as an indication of corruption frequently found in the procurement process. Therefore, in the future the procurement officials should notice the benefit aspect beside the obedient aspect to the rule of law, so that every procurement process can improve the public services which are against the corruption. Even, if necessary, the procurement officials can have a law protection as long as they give the procurement services that give benefits for the people and it does not cause the national or regional financial loss even though it is not in accordance to the procedure ruled in the rule of law.

\section{REFERENCES}

1. Ali, A., Menguak Teori Hukum (Legal Theory) dan Teori Peradilan (Judicialprudence) Termasuk Interprestasi Undang-Undang (Legisprudence). Jakarta: Kencana Media Group, 2010. [16] 292, [17] 289.

2. Amiruddin, Korupsi Dalam Pengadaan Barang dan Jasa. Yogyakarta: Genta Publishing, 2010. [2] 13-14.

3. Atmosudirdjo, P., Hukum Administrasi Negara. Jakarta: Ghalia Indonesia, 1988. [14] 87.

4. Data Penanganan Kasus Korupsi di KPK sampai tanggal 31 Maret 2016 [1].

5. Hamzah, A., Pemberantasan Korupsi: Melalui Hukum Pidana Nasional dan Internasional. Jakarta: PT. Raja Grafindo Persada, 2007. [8] 5.

6. Klitgaard, R., et.al., Corrupt Cities: A Practoca Guide to Cure and Prevention. Jakarta: Yayasan Obor Indonesia, 2005. [3] 29.

7. Marzuki, P.M., Penelitian Hukum (legal research). Jakarta: Prenada Media Group, 2005. [6] 35, [7] 93.

8. Mertokusumo, S., Penemuan Hukum: Sebuah Pengantar. Yogyakarta: Liberty, 2009. [5] 92, [15] 98.

9. Ridwan, H.R., Hukum Administrasi Negara. Jakarta: PT. Raja Grafindo Persada, 2006. [10] 19, [11] 20, [12, 13] 20.

10. Suyatno, Kolusi, Korupsi dan Nepotisme. Jakarta: Pustaka Sinar Harapan, 2005. [9] 17.

11. Termorshuizen, M., Kamus Hukum Belanda-Indonesia. Jakarta: Djambatan, 2002. [4] 103.

12. Undang-Undang Nomor 31 Tahun 1999 tentang Pemberantasan Tindak Pidana Korupsi.

13. Peraturan Presiden Nomor 54 Tahun 2010 tentang Pengadaan Barang dan Jasa Pemerintah. 